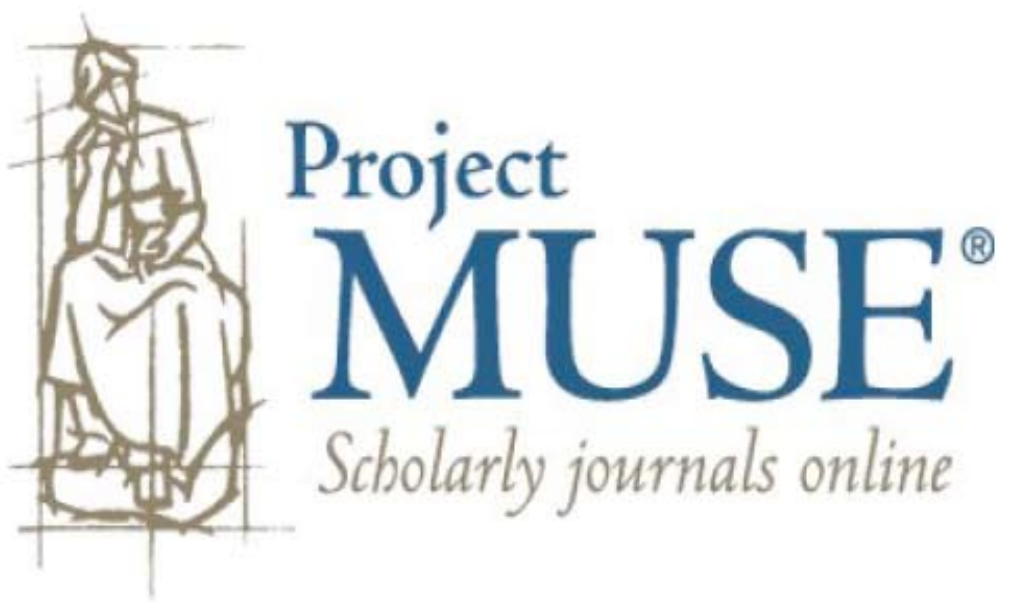




\title{
Squib
}

\section{The Phoneme Inventory of the Aita Dialect of Rotokas}

\author{
Stuart Robinson \\ MAX PLANCK INSTITUTE FOR PSYCHOLINGUSITICS
}

\begin{abstract}
Rotokas is famous for possessing one of the world's smallest phoneme inventories. According to one source, the Central dialect of Rotokas possesses only I I segmental phonemes (five vowels and six consonants) and lacks nasals while the Aita dialect possesses a similar-sized inventory in which nasals replace voiced stops. However, recent fieldwork reveals that the Aita dialect has, in fact, both voiced and nasal stops, making for an inventory of I4 segmental phonemes (five vowels and nine consonants). The correspondences between Central and Aita Rotokas suggest that the former is innovative with respect to its consonant inventory and the latter conservative, and that the small inventory of Central Rotokas arose by collapsing the distinction between voiced and nasal stops.
\end{abstract}

Rotokas is a non-Austronesian (Papuan) language spoken in central Bougainville. According to Wurm and Hattori (I98I), it belongs to the Rotokas family, which includes Keriaka, Eivo, and Kunua (Rapoisi) and arguably belongs to a larger grouping, usually called East Papuan (see Ross [200I] and Dunn et al. [2002, 2005] for commentary). ${ }^{I}$ According to the only systematic survey of the language of Bougainville (Allen and Hurd I963), Rotokas has three main dialects: Aita, Central, and Pipipaia. ${ }^{2}$ There is also a dialect spoken on the west coast in the village of Atsilima (Atsinima) whose status is unclear. Allen and Hurd (I963) refer to it as a "sublanguage." It appears to be heavily influenced by contact with Keriaka; Rotokas speakers describe the language as a "mix" of the two languages.

Central Rotokas is famous for possessing one of the world's smallest inventories of segmental phonemes (Maddieson I984), consisting of only I I phonemes: five vowels and six consonants (Firchow and Firchow I969 [hereafter F\&F]). Another noteworthy feature of Central Rotokas is the lack of "primary nasal consonants" - that is, a phoneme

I. This work, as part of the European Science Foundation EUROCORES program OMLL, was supported by funds from the Nederlandse Organisatie voor Wetenschappelijk Onderzoek (NWO); the Arts and Humanities Research Council, UK; and the EC Sixth Framework program under contract no. ERAS-CT-2003-980409. Many thanks to Michael Dunn, Matthew Leavesley, Ian Maddieson, Gunter Senft, and Claudia Wegener, who read earlier drafts of this squib and provided feedback. All published materials on Rotokas pertain to the Central dialect, and consist of untranslated Rotokas texts (Firchow and Akoitai I974; Firchow I974), a vocabulary (Firchow I973), and a few articles with grammatical analysis (Firchow and Firchow I969 [F\&F]; Firchow I97I, I977, I987).

2. The Central dialect is referred to as "Rotokas Proper" in Allen and Hurd (I963): "These speech groups which have the designation "Proper" (e.g., "Nasioi Proper") are so designated because traditionally they are the center or the origin of their respective languages." However, the term is avoided here because the origin of Rotokas is not actually known, and the term might be construed as biased. 
whose most characteristic allophone is a voiced nasal continuant (Ferguson I966). F\&F lay out the consonant inventory of Central Rotokas as in (I).

$\begin{array}{lccc} & \text { BILABIAL } & \text { ALVEOLAR } & \text { VELAR } \\ \text { VOICELESS } & \mathrm{p} & \mathrm{t} & \mathrm{k} \\ \text { VOICED } & \mathrm{b} & \mathrm{d} & \mathrm{g}\end{array}$

These consonants show a good deal of free variation, making the choice of symbol for a particular phoneme somewhat arbitrary. ${ }^{3}$ For example, the voiced bilabial is variously realized as [ $\beta]$, [b], and [m], while the voiced alveolar is typically realized as a flap.

Although the phonology of the other dialects of Rotokas is largely undescribed, the Aita dialect is known to be less typologically unusual to the extent that it possesses nasal stops. ${ }^{4} \mathrm{~F} \& \mathrm{~F}$ offer (2) as the inventory of consonants for the Aita dialect (274).

$\begin{array}{lccc} & \text { BILABIAL } & \text { ALVEOLAR } & \text { VELAR } \\ \text { VOICELESS (STOPS) } & \mathrm{p} & \mathrm{t} & \mathrm{k} \\ \text { VOICED (NASALS) } & \mathrm{m} & \mathrm{n} & \mathrm{y}\end{array}$

This suggests that the voiced stops of Central Rotokas correspond to nasal stops in Aita. However, during recent fieldwork in Bougainville, the author had the opportunity to work with speakers of Aita Rotokas from the village of Kusi, and found that the phoneme inventory of Aita Rotokas includes both voiced and nasal stops.

A comparison of cognate items in the two dialects reveals that the nasal stops of Aita Rotokas systematically correspond to voiced stops in Central Rotokas, regardless of their position within the word. 5 This is illustrated in table I. However, voiced stops in Central Rotokas do not always correspond to nasal stops in Aita Rotokas, as illustrated by the cognate forms in table 2 , which are identical in form in the two dialects.

There is some allophonic variation in the realization of the consonants of Aita Rotokas. The voiceless alveolar fricative [s] appears to be an allophone of $/ \mathrm{t}$, occurring exclusively before /i/. It was similarly analyzed for Central Rotokas by F\&F. ${ }^{6}$ There is also some free variation, principally in the voiced bilabial, which varies in its manner of articulation between a stop $[\mathrm{b}]$ and a fricative $[\beta]$. The $/ \mathrm{d} /$ is chiefly realized as a flap. Minimal pairs illustrating the various consonant contrasts in word-initial position are provided in table 3 .

No minimal pairs illustrating the contrast between $/ \mathrm{g} /$ and $/ \mathrm{y} /$ were identified, but this is most likely a by-product of the small word list collected and the relative infrequency of these two consonants. (F\&F:273 observe that in Central Rotokas the consonant /g/ also occurs infrequently.) Table 4 provides a revised inventory of the consonant phonemes found in Aita Rotokas.

3. We employ IPA symbols to represent the phonemes of Rotokas. F\&F use non-IPA symbols in some instances; their / $\mathrm{b} /$ and / $\breve{\mathrm{r}} /$ correspond to our /b/ and /d/, respectively. Elsewhere, they use a practical orthography with " $\mathrm{v}$ " and " $\mathrm{r}$ ".

4. The Aita dialect is—or was, in I963, when it was last systematically surveyed—spoken in the villages of Bikuroin, Koibori, Kusi, Nupatoro, Osiwaipa, Owawaipa, Pokoia, Siribia, Tokai, Tsubiai, and Waiano (Allen and Hurd 1963).

5. Because the syllable template of both Central and Aita Rotokas is $(C) V(V)$, and consonant clusters are not permitted, word-internal consonants are invariably intervocalic.

6. This generalization concerning /s/ no longer appears to be true of modern Central Rotokas, possibly due to language contact. There is now widespread bilingualism in Tok Pisin (NeoMelanesian), in which $/ \mathrm{s} /$ and / $\mathrm{t} /$ are distinct phonemes, as reflected in various Tok Pisin loans now found in Rotokas-e.g., the minimal pair tisa "teacher" and sisa "scissors." 
The inventory of vowel qualities in Aita Rotokas appears to be the same as that of Central Rotokas - namely, the same prototypical five-vowel system described for Central Rotokas in F\&F. The various vowel quality contrasts in Aita Rotokas are illustrated by the word sets in (3-5).

(3) a. kaki 'cave'

b. kiki 'kick' (Tok Pisin loan)

c. kuki 'shake'

(5) a. taki 'fasten, peg'

b. teki 'smash'
(4) a. keni 'tear into strips'

b. koni 'mark, carve design'

c. kani 'rip, tear'

c. toki 'look after, care for'

d. tuki 'tear piece off'

\section{TABLE 1. NASALS IN AITA ROTOKAS CORRESPOND TO VOICED CONSONANTS IN CENTRAL ROTOKAS}

$\begin{array}{lclll} & \text { CORRESPONDENCE AITA } & \text { CENTRAL } & \\ \text { WORD-INITIAL } & \mathrm{m} \sim \mathrm{b} & \text { misi } & \text { bisii } & \text { 'you (PL)' } \\ & \mathrm{n} \sim \mathrm{d} & \text { nimuko } & \text { dibuko } & \text { 'mosquito' } \\ & \mathrm{y} \sim \mathrm{g} & \text { nau obi } & \text { gau obi } & \text { 'tear drops' } \\ \text { WORD-INTERNAL } & \mathrm{m} \sim \mathrm{b} & \text { emaoto } & \text { ebaoto } & \text { 'tree' } \\ & \mathrm{n} \sim \mathrm{d} & \text { konato } & \text { koodato } & \text { 'possum' } \\ & \mathrm{g} \sim \mathrm{g} & \text { meyoa } & \text { begoa } & \text { 'jungle' }\end{array}$

TABLE 2. COGNATES IDENTICAL IN FORM IN AITA AND CENTRAL ROTOKAS

$\begin{array}{lcll} & \text { CORRESPONDENCE } & \text { AITA/CENTRAL } & \\ \text { WORD-INITIAL } & \mathrm{b} \sim \mathrm{b} & \text { bokia } & \text { 'day' } \\ & \mathrm{d} \sim \mathrm{d} & \text { daoa } & \text { 'branch' } \\ & \mathrm{g} \sim \mathrm{g} & \text { gibu } & \text { 'beard' } \\ \text { WORD-INTERNAL } & \mathrm{b} \sim \mathrm{b} & \text { abukato } & \text { 'old man' } \\ & \mathrm{d} \sim \mathrm{d} & \text { oidato } & \text { 'man' } \\ & \mathrm{g} \sim \mathrm{g} & \text { sigoa } & \text { 'knife' }\end{array}$

TABLE 3. MINIMAL PAIRS FOR AITA CONSONANTS

\begin{tabular}{lll} 
CONTRAST & \multicolumn{2}{c}{ MINIMAL PAIRS } \\
\cline { 2 - 3 }$/ \mathrm{p} /: \mathrm{b} /$ & padu 'depart' & badu 'unsalted' \\
$/ \mathrm{b} /: / \mathrm{m} /$ & buta 'time' & muta 'taste, feel' \\
$/ \mathrm{p} /: / \mathrm{m} /$ & pone 'turn' & mone 'return' \\
$/ \mathrm{t} /: / \mathrm{d} /$ & tutu 'close' & dutu 'very' \\
$/ \mathrm{d} /: / \mathrm{n} /$ & dito 'hole' & nito 'remove embers' \\
$/ \mathrm{t} /: / \mathrm{n} /$ & toe 'cut' & noe 'this man' \\
$/ \mathrm{k} /: / \mathrm{g} /$ & kade 'return, go back' & gade 'small' \\
$/ \mathrm{k} /: / \mathrm{g} /$ & kati [kasi] 'burn' & nati [nasi]'bend'
\end{tabular}

TABLE 4. AITA CONSONANT PHONEME INVENTORY

$\begin{array}{llll} & \text { BILABIAL } & \text { ALVEOLAR } & \text { VELAR } \\ \text { VOICELESS } & \mathrm{p} & \mathrm{t} & \mathrm{k} \\ \text { VOICED } & \mathrm{b} & \mathrm{d} & \mathrm{g} \\ \text { NASAL } & \mathrm{m} & \mathrm{n} & \mathrm{j}\end{array}$


Unlike Central Rotokas, Aita Rotokas does not appear to possess a vowel length distinction. Various minimal pairs for vowel length in Central Rotokas (e.g., buta 'taste, feel' vs. buuta 'time') were sought in Aita Rotokas, but none was found to carry over.

Given the sound correspondences between the two dialects (cf. tables I and 2), the reconstruction of Proto-Rotokas appears to require the postulation of a sound change whereby nasality was lost in Central Rotokas (rather than acquired by Aita Rotokas). In other words, Aita Rotokas is conservative with respect to nasality, whereas Central Rotokas is innovative.

This finding represents one small piece in the larger puzzle of how the typologically unusual phonology of Central Rotokas evolved. A more complete understanding must await the collection of more data from the other dialects of Rotokas and from the other languages in the Rotokas family, which is still almost entirely undocumented.

\section{REFERENCES}

Allen, Jerry, and Conrad Hurd. I963. Languages of the Bougainville district. Ukarumpa: Summer Institute of Linguistics.

Dunn, Michael, Ger Reesink, and Angela Terrill. 2002. The East Papuan languages: A preliminary typological appraisal. Oceanic Linguistics 4I:28-62.

Dunn, Michael, Angela Terrill, Ger Reesink, Robert A. Foley, and Stephen C. Levinson. Structural phylogenetics and the reconstruction of ancient language history. 2005. Science 309:2072-75.

Ferguson, Charles A. I 966 . Assumptions about nasals. In Universals of language, ed. by Joseph H. Greenberg, 53-60. Cambridge, Mass.: MIT Press.

Firchow, Irwin B. I973. A vocabulary of Rotokas. Ukarumpa: Summer Institute of Linguistics. . I97I. Rotokas referentials. Kivung 4:175-86. , ed. I974. Rotokasipairara pitupituaro / Rotokas customs. Ukarumpa: Summer Institute of Linguistics.

- I977. Some functions of Rotokas referentials. In Workpapers in Papua New Guinea Languages, vol. 20, ed. by Richard Loving and David Thomas, I33-42. Ukarumpa: Summer Institute of Linguistics.

- 1987. Form and function of Rotokas words. Language and Linguistics in Melanesia I 5:5-I I I.

Firchow, Irwin B., and David Akoitai, ed. 1974. Rotokas reo vo siposiporoaro vo toupai / Rotokas stories. Ukarumpa: Summer Institute of Linguistics.

Firchow, Irwin B., and Jacqueline Firchow. 1969. An abbreviated phoneme inventory. Anthropological Linguistics I I:27 I-76. [F\&F]

Maddieson, Ian. I984. Sound patterns of language. Cambridge: Cambridge University Press.

Ross, Malcolm. 200I. Is there an East Papuan phylum? Evidence from pronouns. In The boy from Bundaberg: Studies in Melanesian linguistics in honour of Tom Dutton, ed. by Andrew Pawley, Malcolm Ross, and Darrell Tryon, 30I-2 I. Canberra: Pacific Linguistics.

Wurm, Stephen, and S. Hattori. I98 I. Language atlas of the Pacific area. Canberra: Australian Academy of the Humanities.

Max Planck Institute for Psycholinguistics

Postbus 3 IO

6500 AH Nijmegen

The Netherlands

Stuart.Robinson@mpi.nl 